\title{
Women's Candidacy in Local Level Elections, 2017
}

\author{
Amrit Kumar Shrestha, $\mathrm{PhD}^{1}$ \\ Shyam Prasad Phuyel ${ }^{2}$
}

\begin{abstract}
Local levels have emerged as an epicenter of national politics. They influence the province and federal levels. Nepal has 753 local levels; among them 293 are municipalities and 460 are rural municipalities (RM). Women's candidacy in electoral politics is a key issue of political discourse. After the people's movement of 2006, Nepal has made several constitutional and legal reformations in regarding of inclusion of women in politics, particularly at local levels. This article focuses on women candidacy at the local level election of Nepal that held in 2017. It is based on data published by the Election Commission of Nepal. The election result indicates a positive change in terms of women's participation at the local level. Although most of the women are cast at the post of deputy mayor or vice-president of RM, 718 women are entertaining the executive post of the local level. This article analyzes women's participation as a candidate and elected candidate in various posts and positions of local level comparing to their counter partner men candidates.
\end{abstract}

Keywords: municipality, rural municipality, candidacy, election, post.

\section{Introduction}

Local levels are considered as the base of the politics of the country. It is also supposed as a training center to produce leaders for the higher level. The election is a peaceful means to enter into political power. To participate as a candidate in the election is itself an important mode of politics; to be elected in the election is another significant achievement for any politician. The participation of women in the election is a rare phenomenon for the long period of Nepalese political scenario. It happened because the political model is set up as a masculine model (Shvedova, 2005). However, the scenarios are seeing change. After the peoples' movement of 2006, Nepalese women's participation in electoral politics has been significantly increased.

In the History of Nepal, the first election of the local level was held in June 1947 that was held to elect the member of Kathmandu municipality (Gupta, 1964). Only adult males were granted the voting right in the election. Some days before the election, representatives of

1 Principal author, Associate Professor, Department of Political Science Education, Central Department of Education, Kirtipur, Tribhuvan University, Nepal. Email: amrit365@gmail.com

2 Corresponding author, Lecturer, Department of Political Science Education, Central Department of Education, Kirtipur, Tribhuvan University, Nepal. Email: shyamphuyal0@ gmail.com 
women, in the leadership of Shreemaya, went to Bishalnagar, the residence of the then prime minister Padma Shamsher and demanded equal voting rights to women as provided to men. The prime minister replied to them that because of a short period and first experience of the election, it would be impossible to give voting right for women but would be considered about it in the future (Pradhan, 2047 BS).

Another election of the Kathmandu municipality was held on 1 September 1953, the first election since the political change of 1951. Among the elected ward councilor of the municipality, there was only a woman candidate and she was Sadhana Pradhan (Malla, 2011). She became the first elected woman in the political history of Nepal.

Nepal's first House of Representatives election took place in 1959 to elect its 109 members. It was Nepal's first experiment with general elections. Voting started on 18 February and lasted two months due to the difficulty of transporting ballot boxes to and from remote areas (Thapa, 2013). Only six women were in the elections race of 1959. It was only 0.76 percent of total candidates. Among these candidates, Dwarika Devi Thakurani, a single woman, won the election (Lama, Khakurel, Agrawal, \& Shrestha, 2011). A handful number of women could win the elections of local to the national level in the Panchayat period (Chalise, 1995).

After the restoration of multiparty democracy in 1990, three national elections were held to elect the members of the House of Representatives (HoR). As table-1 shows, women candidates could not cross the ceiling of 6.39 percent in these elections. The number of elected women candidates was 7 in both first and second elections of the HoR out of 205 seats. In the third election of 1999, 12 women candidates could secure their seats in the HoR. In another word, the percentage of elected women was only from 3.41 to 5.85 in three elections of the HoR.

Table 1: Gender-wise candidates of general elections of Nepal

\begin{tabular}{|c|c|c|c|c|c|c|c|c|c|c|c|c|}
\hline \multirow{3}{*}{ Gender } & \multicolumn{4}{|c|}{ Election of 1991} & \multicolumn{4}{|c|}{ Election of 1994} & \multicolumn{4}{|c|}{ Election of 1999} \\
\hline & \multicolumn{2}{|c|}{ Candidates } & \multicolumn{2}{|c|}{ Elected } & \multicolumn{2}{|c|}{ Candidates } & \multicolumn{2}{|c|}{ Elected } & \multicolumn{2}{|c|}{ Candidates } & \multicolumn{2}{|c|}{ Elected } \\
\hline & $\mathrm{N}$ & $\%$ & $\mathrm{~N}$ & $\%$ & $\mathrm{~N}$ & $\%$ & $\mathrm{~N}$ & $\%$ & $\mathrm{~N}$ & $\%$ & $\mathrm{~N}$ & $\%$ \\
\hline & 265 & & 198 & 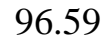 & 356 & & 198 & 96 & 2,095 & 61 & 193 & 94.15 \\
\hline & 80 & & 7 & & 86 & 5.96 & 7 & 3.41 & 143 & 6.39 & 12 & 5.85 \\
\hline tal & 45 & 0.00 & 205 & 0.00 & 442 & 0.00 & 5 & 00.00 & 238 & 00.00 & 0 & 00.00 \\
\hline
\end{tabular}

Note: Data extracted from Election Commission 1992, 2051 BS, \& 2056 BS

After the political change of 1990, two elections were held to elect the people's representatives for the local bodies. The local bodies were divided into 3 sections - District Development Committee (DDC) at the district level, Municipalities (Metropolitan city, Sub-metropolitan city, and Municipality) in the town area, and Village Development Committee (VDC) in the village area. DDCs comprise 1,077 members, including 75 District Development Chairpersons. There were altogether 58 municipalities, from which, 4,147 members should be elected. 
Likewise, there were 3,913 VDCs, out of which 183,911 should be elected (Election Commission, 2015). In the first local elections in 1992, only 0.5 percent of women could represent out of 189,210 seats of local bodies (NDIIA, 2001).

The second election for local bodies held in 1997 (Election Commission, 2015). The government declared an ordinance on 4 April 1997, which amended the then DDC Act 1992, Municipality Act 1992, and VDC Act 1992. The ordinance introduced mandatory women's representation in local government. The local elections 1997 were held according to new legal provisions. So, women's participation had increased dramatically in the local elections in comparison to 1992 's local elections. For instance, about 100,000 women filed their candidacy in the election and 40,533 women were elected in local government as a direct result of these compulsory provisions (Bennett, Sijapati, \& Thapa, 2013).

So far as executive positions are concerned, women candidates comprised only less than $1 \%$ of wards chairs across the country. In the 58 municipalities across the country, seven women ran for mayor and six for deputy mayor, but none of them won the election. And for the total of 3,913 VDC chair and vice-chair positions in the country, 40 and 82 women respectively contested the elections; of these 17 ( $0.43 \%$ of the total positions) were elected as VDC chairs and $15(0.38 \%)$ as vice-chairs (Chhetri, 2013).

After the people's movement in 2006, the election of the constituent assembly (CA) had become the main national agenda of Nepal. After the many times postponed and negotiations the first CA elections had held on 10 April 2008, millions of Nepali people took part to cast vote their representatives, and they had been waiting for the new constitution. The CA was the most diverse and inclusive legislature in the history of Nepal, where people from all walks of life, belonging to different social groups and with different ideologies had participated in the constitution-making process (Hachhethu, 2009).

Through the CA elections, Nepal had made some historic record on women's participation in electoral politics ever before. There were nearly 33 percent of women members in the CA (Table-2). Consequently, Nepal had outstripped all the countries of the region regarding women's representation, and ranked 14th in the world, in the gender index (Manchanda, 2008). The CA was a mixed group of women with Pratibha Rana of the royalist party RPP and her daughter Arzu Deuba of NC side by side with the CPN (UML)'s Savita [Shanta] Chaudhari, a former bonded laborer (Manchanda, 2008).

After nearly four years of political negotiation, in May 2012 the Constituent Assembly got dissolved before it could finalize the long-awaited constitution (Pokharel \& Rana, 2013). Immediately, new CA elections had been declared. After two postponements, finally, the CA elections were held on 19 November 2013. 
Table 2: Women in the CA

\begin{tabular}{lccccr}
\hline \multirow{2}{*}{\multicolumn{1}{c}{ Method of Entry }} & \multicolumn{2}{c}{ CA 2008 } & \multicolumn{2}{c}{ CA 2013 } & \multirow{2}{*}{$\begin{array}{c}\text { Total } \\
\text { Seat }\end{array}$} \\
\cline { 2 - 5 } & Number & Percentage & Number & Percentage & Sear \\
\hline First-past-the-post & 30 & 12.5 & 10 & 4.2 & 240 \\
Proportional Representation & 161 & 48.1 & 162 & 48.4 & 335 \\
Nomination & 6 & 23.1 & 4 & 15.4 & 26 \\
\hline Total & 197 & 32.8 & 176 & 29.3 & 601 \\
\hline
\end{tabular}

Note: Data extracted from RSN, 2009; Election Commission, 2070a and 2070b

As shown in table-2, CA 2013 has also a notable number of women. However, the percent of women members slightly decreased from 32.8 to 29.3 in 2013. Through the FPTP electoral system, the number of women members drastically dropped down from 30 to 10 in 2013's election. Compensation was tried to fulfill through the proportional representation system. Consequently, there was near about 30 percent of women members in the role of enacting a new constitution for the country.

\section{Review of Literature}

A visible number of research works have been conducted regarding the issue of women's participation in electoral politics. These studies mainly focus on the electoral politics of European and American countries. Though to a small extent, scholars have also contributed to the Nepalese context, too, regarding women's participation in elections. The text that follows is an attempt to review the related literature.

According to Palanithurai (2002), after the provision of reservations to women in the local bodies, there has been a tremendous increase in the number of women representatives in the Panchayati raj institutions in India. He adds that to increase women's empowerment it requires a change in the social institutions, people's mindset, and far more determined effort on the part of the women representatives.

Kudva (2003) finds that through gender quotas is a crucial component of strategies that seek to empower women through increased participation in the political system. In the south Indian state of Karnataka, this experiment has seen positive results: it has made women more visible in Panchayati Raj institutions and increased self-efficiency of women representatives.

Dahlerup and Freidenvall (2005) examine the incremental track versus the fast track to women's representation. Incremental track believes in gradual development and progress. In contrast, the fast track discourse rejects the idea of gradual improvement in women's participation in politics. The fast track discourse represents the impatience of feminists who are not willing to wait for decades to achieve their goals. They aim to produce a rapid and immediate change. They find that about forty countries in all the major regions of the world have introduced gender quotas for election, although it is highly controversial. Women's 
representation in Costa Rica's parliament jumped overnight from 19 to 35 percent in 2002; whereas in Denmark, 38 percent of members of parliament were women in 2001, it took twenty years of incremental increase over eight elections.

Kumar (2010) argues that gender issue becomes very sensitive mostly when political parties are pressurized by donors to make it socially relevant. Political parties are unwilling to support women's candidacy in elections unless they are tied to the name and fame of their family or men. Another feature of the women candidates is that most of them are successors either to they are deceased, murdered, or slain husbands. Women candidates are also used for capitalizing on popular sympathy rather than on merit. In other words, they are used almost as vote-catchers.

Lawless \& Fox (2010) premise their analysis on the hypothesis that men and women are not equally interested in running for office. Based on the Citizen Political Ambition Survey, eligible men and women candidates in professions (lawyers, business leaders and executives, educators, and political activists) most suited to political office, the authors identify a gender gap in political ambition between men and women. They find that women and men have similarities in levels of political participation, proximity, and interest in politics but fewer women willing to be a candidate for public office than men. Similarly, women are more likely than men to run for local-level offices, whereas men are more likely to seek state-level positions.

Gilardi (2015) finds that one of the main obstacles to closing the gender gap in politics is the insufficient number of women willing to run for office. Her study on women's political representation in 168 municipalities of the Swiss canton of Zurich from 1970 to 2010 concludes that more women ran for office if more women were elected in nearby municipalities in the previous election.

Several studies have been carried out in the case of women's participation in electoral politics. However, they are not sufficient in women's candidacy in the election, particularly in the local level election. There are very scant kinds of literature found in this area within the Nepalese context. This article tries to search the facts about women candidacy at the local level election that recently held in Nepal in 2017.

\section{Research problem}

Nepal has made constitutional and legal reforms for more women participation in elections, particularly at the local level. Following the new provision, the election for the local level was held in 2017. It is an important issue to understand the position of women in the local level election in reference to the new legal provision. In this endeavor this article seeks the answer to the following research questions:

- How many women candidates participated and won the election? 
- What was the position of women regarding posts of the local level, within geographical regions, and political parties as candidates and winners?

\section{Objectives}

The general objective of this article is to critically examine the participation of women as candidates in the local level election of Nepal that held in 2017. Its especial objectives are as follows:

- to find out the number of women candidates and winner of the local level election.

- to compare the distribution of women's candidacy in posts of local level, geographical regions, and political parties with men.

\section{Research methodology and conceptual framework}

This article primarily used data published by the Election Commission of Nepal of the election result of the local level, 2017. Similarly, related electronic databases were also consulted. Descriptive and analytical research designs were used for the analysis. The number of women candidates was compared to men at different level i.e. posts of local levels, political parties, and province, etc. The comparison also made between women and men as winner candidates.

Liberal feminism is the underpinning philosophical view of this article. Liberal feminists believe in gradual reform in legal and political structures (Tong, 2009). They believe in a democracy where every group of people, including women, would gain their equal rights by democratic way and process. After the peoples' movement of 2006, Nepal has made many constitutional and legal changes in issues of women's participation in electoral politics. The number of women is increasing in comparison to the past. So, this article tries to shed light on the result of the local level election in the reflection of legal reformations.

\section{Result and discussion}

The election of local levels was held in 2017 as per a new provision of the constitution of Nepal, 2015 and election of the local level act, 2017. These elections were completed in three phases in all over the country. New constitutional and legislative provisions open the door to women for more opportunities to participate in elections at the local level. This article tries to analyze the impact of these theoretical provisions on the practical reality of the election of the local level.

\section{Candidates of Local Level Elections, 2017}

Local levels were reconstructed just before the elections. According to the new provision, there are altogether 753 local levels; among them 293 are municipalities and 460 are Rural Municipalities (RM). Municipalities are divided into three categories - metropolitan, submetropolitan, and municipalities. There are 6 metropolitan, 11 sub-metropolitan and 276 
municipalities in the country (MoFAGA, 2017). In the context of this article, these all three types are collectively called 'municipality' except the particularly mentioned. As table-3 shows, province 1 has the highest number of local levels and province 6 has the lowest.

Table 3: Number of local levels

\begin{tabular}{ccccc}
\hline Province & Municipality & Rural Municipality & Total Local Level & Ward \\
\hline 1 & 49 & 88 & 137 & 1,156 \\
2 & 77 & 59 & 136 & 1,271 \\
3 & 45 & 74 & 119 & 1,121 \\
4 & 27 & 58 & 85 & 759 \\
5 & 36 & 73 & 109 & 983 \\
6 & 25 & 54 & 79 & 718 \\
7 & 34 & 54 & 88 & 734 \\
\hline Total & 293 & 460 & 753 & 6,742 \\
\hline
\end{tabular}

Note: Data extracted from MoFAGA, 2017

In the local level election (2017), there were altogether 148,362 candidates in elections fray. Among them 90,516 (61.01\%) were men and 57,844 (38.99\%) were women. There were only two candidates from the third gender. So, this article focuses only on men and women candidates; although authors honor third gender and their rights.

Table 4: Gender-wise candidates of local level elections 2074

\begin{tabular}{lrrrrrrr}
\hline \multicolumn{1}{c}{ Post } & Total & Man & Man\% & Woman & Woman\% & $\begin{array}{c}\text { Third } \\
\text { Gender }\end{array}$ & TG\% \\
\hline Mayor & 2,951 & 2,735 & 92.68 & 215 & 7.29 & 1 & 0.03 \\
Deputy Mayor & 2,106 & 427 & 20.28 & 1,679 & 79.72 & 0 & 0.00 \\
President of RM & 2,886 & 2,733 & 94.70 & 153 & 5.30 & 0 & 0.00 \\
Vice-President of RM & 2,258 & 344 & 15.23 & 1,914 & 84.77 & 0 & 0.00 \\
Ward Chairperson & 32,267 & 31,209 & 96.72 & 1,057 & 3.28 & 1 & 0.00 \\
Member & 55,090 & 53,068 & 96.33 & 2,022 & 3.67 & 0 & 0.00 \\
Women Member & 26,708 & 0 & 0.00 & 26,708 & 100.00 & 0 & 0.00 \\
Dalit Women Member & 24,096 & 0 & 0.00 & 24,096 & 100.00 & 0 & 0.00 \\
\hline Grand Total & 148,362 & 90,516 & 61.01 & 57,844 & 38.99 & 2 & 0.00 \\
\hline
\end{tabular}

Note: Data extracted from Election Commission, 2074 BS

Men candidates overwhelmed the candidacy for apex post of local levels. As table-4 shows, more than 92 percent of candidacy for the post of Mayor were men. Similarly, more than 94 percent of men filled their candidacies for president of RM. According to the provision of section 17(4) of the local level election act, 2017, the political party has to at least 50 percent woman candidate in the post of chief and vice-chief of the local level while they were filing 
nomination forms. Parties obeyed the election law; however, they filled most of the women candidates' nomination on the post of vice-chief of the local level. According to table-4, only about seven percent of candidates of the mayor and five percent of candidates of the president of RM were women in the local level elections of 2017 throughout the country.

Article 222(3) of the constitution of Nepal (2015) has reserved two seats (out of four) of members of the ward committee. Section 6(2) of the local level election act (2017) has additionally reserved one seat for dalit women. As these constitutional and legal provisions, 50,804 women got experience of the candidacy of elections and among them, 24,096 were dalit women. The post of chairperson and two members of the ward committee were left open; where less than four percent of women nominated in these posts in comparison to men.

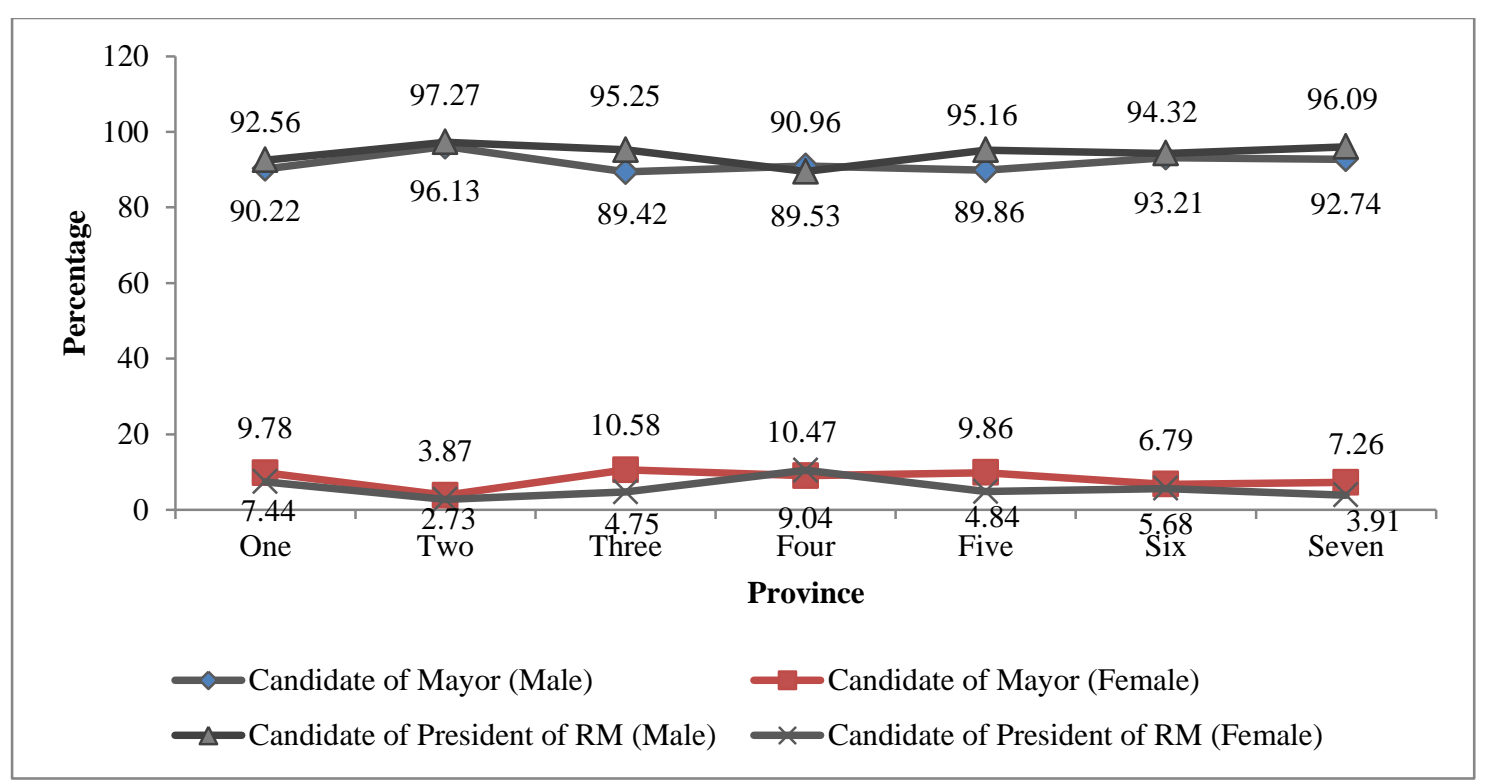

Figure 1: Gender-wise candidates of chief and vice-chief of local levels

In the post of mayor of municipalities, province 2 had the least percent of women candidates whereas province 3 had the highest percent of women candidates. If one compares the ratio of man and woman candidates, she finds a huge gap between them. For example, there was one woman among 25 men candidates of mayor in the province two. Similarly, in the post of president of RM, men candidates occupied about 90 percent seat. In the province two, there were less than 3 percent women candidates in the post, where hardly one woman candidate found among the multitude of 36 men candidates of the president of RM. Comparatively, condition of the province four was more satisfactory, where more than 10 percent of women filled their candidacy on the post of president of the RM.

As figure-2 shows, many women candidates got a chance to entertain candidacy of deputy mayor of the municipality because of the mandatory provision of the election law. There 
was more than 89 percent of women candidates for deputy mayor of the municipality in province six. However, province five comprised less than 70 percent of women candidates of deputy mayor in spite of the favorable legal provision and such an inclusive political environment of the nation. Likewise, in the post of vice-president of the RM, province one had the least number of women candidates and province seven had the highest.

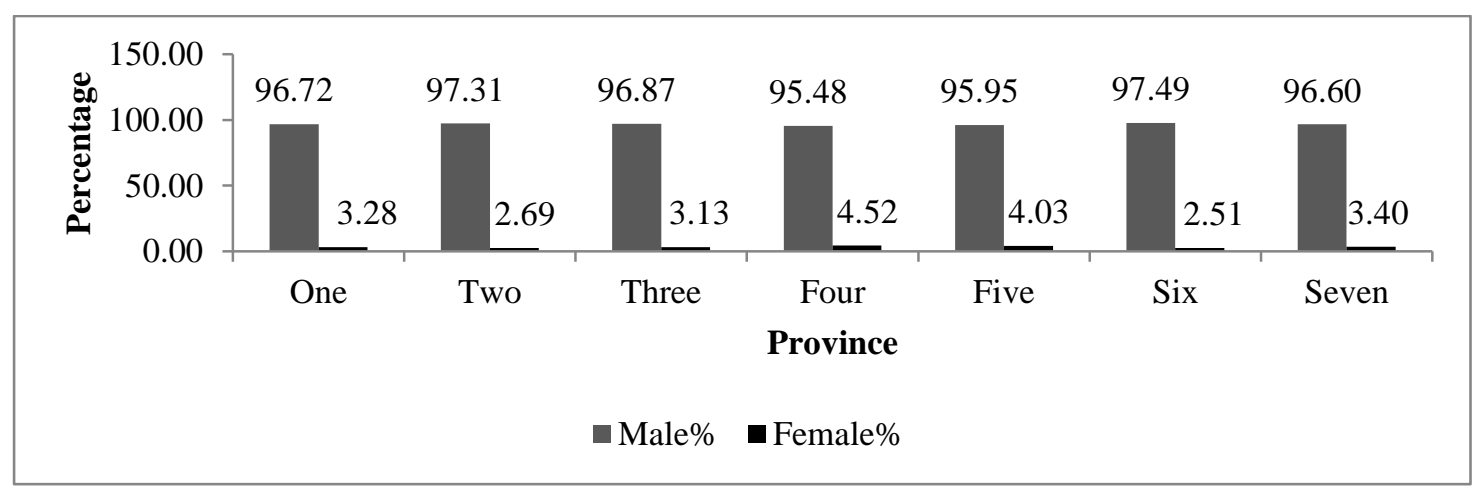

Figure 2: Candidates of Ward Chairpersons

The post of ward chairperson was left open, where the number of women candidates was very small as the comparison of men candidates. In the province level, province 4 had 4.52 percent of women candidates in the post of ward chairpersons that was the highest percent in comparison to the other provinces. Province 6 had the lowest women candidates for the post where only 2.51 percent of women candidates were in the field of elections of ward chairperson.

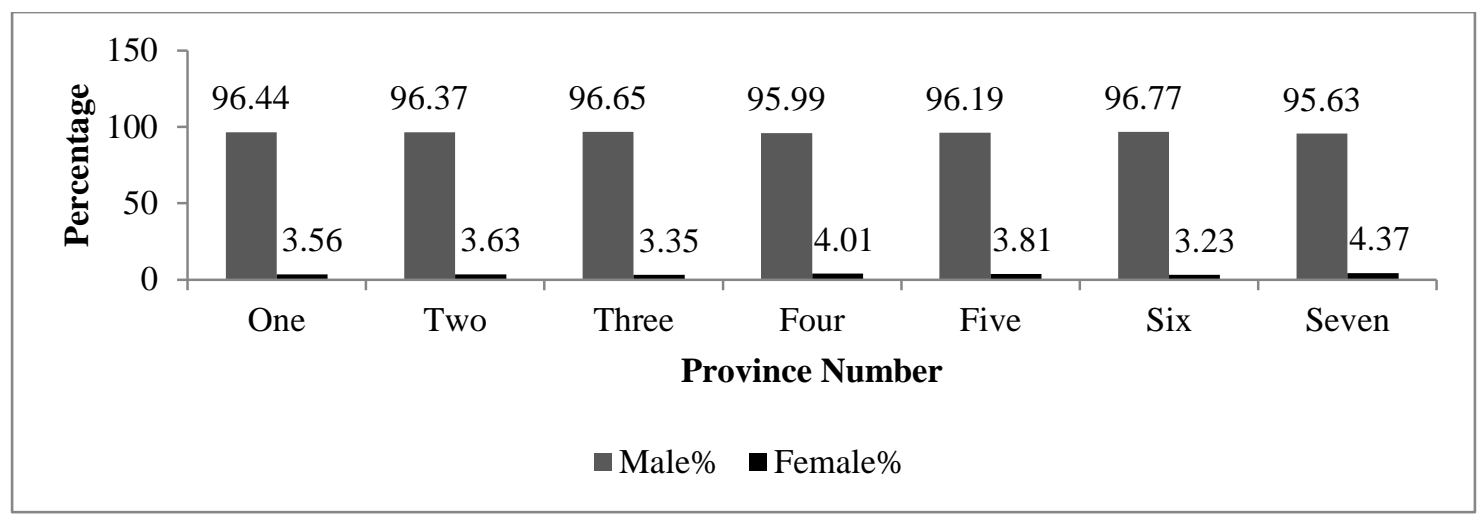

Figure 3: Candidates of ward committee members

Similarly, out of four members of the ward committee, two members were left open for all. In the post, as figure- 3 shows, the condition of women candidates was very poor. Province 7 had 4.37 percent women candidates and it was the highest number of women candidacy in comparison to the other six provinces. 


\section{Elected Candidates}

Altogether 35,041 candidates were elected for all posts of local levels. As table-5 shows, among them, 59.04 percent were men and 40.96 percent were women. In the post of chiefs of the local level were overwhelmed by men. Altogether 97.61 percent elected mayors of municipalities were men. Only seven women won the post of mayor. Renu Dahal was an only woman candidate who won the post of mayor of the metropolitan (Bharatpur, Chitawan). Other six women mayors of municipalities were Rina Kumari Sah (Moulapur, Routahat), Prabha Baral (Rapti, Chitawan), Sima Kumari Chetri (Putalibajar, Syanja), Chandra Kumari Pun (Kawasoti, Nawalaparasi), Kantika Sejuwal (Chandananath, Jumla) and Manju Malasi (Dipayal Silgadhi, Doti). No woman candidate elected on the post of mayor of Sub-Metropolitan city.

Men dominated the elected candidates of the post in the president of the RM. According to table-5, altogether 449 men and 11 women won the post out of $460 \mathrm{RM}$ of the country. The elected candidates of most of the post of deputy mayor of the municipality and vice-president of the RM were women. It happened because the political parties had fielded most of the women candidates in these posts.

Table 5: Post-wise elected candidates

\begin{tabular}{lrrrrr}
\hline Post & Total & Man & Man\% & Woman & Woman\% \\
\hline Mayor & 293 & 286 & 97.61 & 7 & 2.39 \\
Deputy Mayor & 293 & 17 & 5.80 & 276 & 94.20 \\
President of RM & 460 & 449 & 97.61 & 11 & 2.39 \\
Vice-President of RM & 460 & 36 & 7.83 & 424 & 92.17 \\
Ward Chairperson & 6,742 & 6,680 & 99.08 & 62 & 0.92 \\
Member & 13,484 & 13,220 & 98.04 & 264 & 1.96 \\
Women Member & 6,742 & 0 & 0.00 & 6,742 & 100.00 \\
Dalit Women Member & 6,567 & 0 & 0.00 & 6,567 & 100.00 \\
\hline Grand Total & 35,041 & 20,688 & 59.04 & 14,353 & 40.96 \\
\hline
\end{tabular}

Note: Data extracted from Election Commission, 2074 BS

The ward chairperson's post was unreserved, where more than 99 percent of elected candidates were men. Similarly, more than 98 percent of men won in the two unreserved ward members' seats across the country. However, 6,742 women could entertain the post of women ward members and 6,567 dalit women elected as members of the ward committee. It was possible because of the reservation of these seats only for women. Unfortunately, 175 dalit women member's seats were left vacant because of the lack of presence of dalit women in the concerned ward. 


\section{Party-wise women candidates}

Forty-five political parties participated in the local level election 2017 with their candidates. Among the 148,362 candidates, 140,265 were partisan candidates and remaining were independents.

Table 6: Political party-wise candidates

\begin{tabular}{|c|c|c|c|c|c|c|c|}
\hline \multirow{2}{*}{ Political Party } & \multirow{2}{*}{ Candidates } & \multicolumn{2}{|c|}{ Man } & \multicolumn{2}{|c|}{ Woman } & \multicolumn{2}{|c|}{ Other } \\
\hline & & $\mathbf{N}$ & $\%$ & $\mathbf{N}$ & $\%$ & $\mathbf{N}$ & $\%$ \\
\hline Nepali Congress & 33,553 & 19,889 & 59.28 & 13,664 & 40.72 & 0 & 0.00 \\
\hline Communist Party of Nepal (UML) & 33,174 & 19,473 & 58.70 & 13,701 & 41.30 & 0 & 0.00 \\
\hline t Party c & 30,250 & 17,825 & 58.93 & 12,425 & 41.07 & 0 & 0.00 \\
\hline Rashtriya Prajatantra Part & 13,144 & 8,326 & 63.34 & 4,818 & 36.66 & 0 & 0.00 \\
\hline Sangiya Samajbadi Forum, Nepal & 8,135 & 4,914 & 60.41 & 3,221 & 39.59 & 0 & 0.00 \\
\hline Rashtriya Janata Party, Nepal & 4,934 & 2,957 & 59.93 & 1,977 & 40.07 & 0 & 0.00 \\
\hline Naya Shakti Party, Nepal & 3,886 & 2,480 & 63.82 & 1,405 & 36.16 & 1 & 0.03 \\
\hline Madheshi Janaadhikar Forum, Nepal (Loktantrik) & 2,864 & 1,721 & 60.09 & 1,143 & 39.91 & 0 & 0.00 \\
\hline Rashtriya Janmorch & 2,391 & 1,464 & 61.23 & 927 & 38.77 & 0 & 0.00 \\
\hline Others & 7,934 & 4,785 & 60.31 & 3,148 & 39.68 & 1 & 0.01 \\
\hline Independent & 8,097 & 6,682 & 82.52 & 1,415 & 17.48 & 0 & 0.00 \\
\hline Total & 148,362 & 90,516 & 61.01 & 57,844 & 38.99 & 2 & 0.00 \\
\hline
\end{tabular}

Note: Data extracted from Election Commission, 2074 BS

As table- 6 shows, the big three parties (NC, CPN-UML, and CPN-Maoist Centre) fielded more women candidates in the election. Where CPN-UML was in top position in this regard, NC was in second, and CPN-Maoist Centre was in the third position respectively. Altogether 1,415 women candidates filed their nomination independently in the election.

Table 7: Political party-wise elected candidates

\begin{tabular}{lrrrrr}
\hline \multirow{2}{*}{ Political Party } & \multirow{2}{*}{ Total } & \multicolumn{2}{c}{ Man } & \multicolumn{2}{c}{ Woman } \\
\cline { 3 - 6 } & & \multicolumn{1}{c}{$\mathbf{N}$} & $\mathbf{\%}$ & \multicolumn{1}{c}{ N } & \multicolumn{1}{c}{$\%$} \\
\hline Communist Party of Nepal (Unified Marxist-Leninist) & 14,097 & 8,158 & 57.87 & 5,939 & 42.13 \\
Nepali Congress & 11,458 & 6,892 & 60.15 & 4,566 & 39.85 \\
Communist Party of Nepal (Maoist Centre) & 5,441 & 3,230 & 59.36 & 2,211 & 40.64 \\
Sangiya Samajbadi Forum, Nepal & 1,439 & 830 & 57.68 & 609 & 42.32 \\
Rashtriya Janata Party, Nepal & 1,112 & 651 & 58.54 & 461 & 41.46 \\
Others & 1,261 & 754 & 59.79 & 507 & 40.21 \\
Independent & 233 & 173 & 74.25 & 60 & 25.75 \\
\hline Total & 35,041 & 20,688 & 59.04 & 14,353 & 40.96 \\
\hline
\end{tabular}

Note: Data extracted from Election Commission, 2074 BS 
Only 18 political parties could win their candidates in the post of the local level. Among them, as table-7 shows, the CPN-UML was posted in number one position per both number and percentage of elected women candidates. The NC was in second and the CPN-Maoist Centre was in the third position. Sixty independent women candidates could win the election.

Table 8: Party-wise elected candidates at major post of local level

\begin{tabular}{|c|c|c|c|c|c|c|c|c|}
\hline \multirow{2}{*}{ Political Party } & \multicolumn{2}{|c|}{ Mayor } & \multicolumn{2}{|c|}{ Deputy Mayor } & \multicolumn{2}{|c|}{$\begin{array}{l}\text { President of } \\
\text { RM }\end{array}$} & \multicolumn{2}{|c|}{$\begin{array}{l}\text { Vice-President } \\
\text { of RM }\end{array}$} \\
\hline & Man & Woman & Man & Woman & Man & Woman & Man & Woman \\
\hline $\begin{array}{l}\text { Communist Party of Nepal } \\
\text { (Unified Marxist-Leninist) }\end{array}$ & 119 & 4 & 8 & 129 & 168 & 3 & 8 & 186 \\
\hline Nepali Congress & 104 & 1 & 2 & 82 & 156 & 5 & 10 & 129 \\
\hline $\begin{array}{l}\text { Communist Party of Nepal } \\
\text { (Maoist Centre) }\end{array}$ & 32 & 2 & 5 & 38 & 69 & 3 & 10 & 58 \\
\hline Rastriya Janata Party, Nepal & 14 & 0 & 0 & 17 & 11 & 0 & 0 & 13 \\
\hline Sangiya Samajbadi Forum, Nepal & 10 & 0 & 0 & 6 & 24 & 0 & 2 & 24 \\
\hline Nepal Majadur Kisan Party & 1 & 0 & 0 & 1 & 0 & 0 & 0 & 0 \\
\hline Nepal Lokatantrik Forum & 1 & 0 & 0 & 1 & 2 & 0 & 0 & 2 \\
\hline Nepali Janata Dal & 1 & 0 & 0 & 0 & 1 & 0 & 0 & 0 \\
\hline $\begin{array}{l}\text { Madheshi Janaadhikar Forum, } \\
\text { Nepal (Loktantrik) }\end{array}$ & 1 & 0 & 0 & 1 & 5 & 0 & 0 & 4 \\
\hline Rastriya Prajatantra Party & 1 & 0 & 2 & 1 & 4 & 0 & 0 & 4 \\
\hline Naya Shakti Party, Nepal & 0 & 0 & 0 & 0 & 2 & 0 & 0 & 1 \\
\hline Rastriya Janamorch & 0 & 0 & 0 & 0 & 3 & 0 & 1 & 3 \\
\hline Independent & 2 & 0 & 0 & 0 & 4 & 0 & 5 & 0 \\
\hline Grand Total & 286 & 7 & 17 & 276 & 449 & 11 & 36 & 424 \\
\hline
\end{tabular}

Note: Data extracted from Election Commission, 2064 BS

According to table-8, on the one hand, a large number of men candidates won the post of chiefs of local level as partisan candidates, on the other hand, a very scant women candidate could win the post; they were limited on vice-chiefs of local level. It happened because the candidacy of men and women was fixed in this pattern by the political parties. 
Table 9: Party-wise elected candidates at ward committee

\begin{tabular}{|c|c|c|c|c|c|c|c|c|}
\hline \multirow{2}{*}{ Political Party } & \multicolumn{2}{|c|}{$\begin{array}{c}\text { Ward } \\
\text { Chairperson }\end{array}$} & \multicolumn{2}{|c|}{ Member } & \multicolumn{2}{|c|}{$\begin{array}{l}\text { Women } \\
\text { Member }\end{array}$} & \multicolumn{2}{|c|}{$\begin{array}{l}\text { Dalit Women } \\
\text { Member }\end{array}$} \\
\hline & Man & Woman & Man & Woman & Man & Woman & Man & Woman \\
\hline $\begin{array}{l}\text { Communist Party of Nepal } \\
\text { (Unified Marxist-Leninist) }\end{array}$ & 2,529 & 31 & 5,326 & 132 & 0 & 2,776 & 0 & 2,678 \\
\hline Nepali Congress & 2,270 & 16 & 4,350 & 73 & 0 & 2,157 & 0 & 2,103 \\
\hline $\begin{array}{l}\text { Communist Party of Nepal } \\
\text { (Maoist Centre) }\end{array}$ & 1,095 & 7 & 2,019 & 37 & 0 & 1,036 & 0 & 1,030 \\
\hline Rastriya Janata Party, Nepal & 193 & 2 & 433 & 4 & 0 & 211 & 0 & 214 \\
\hline $\begin{array}{l}\text { Sangiya Samajbadi Forum, } \\
\text { Nepal }\end{array}$ & 259 & 3 & 535 & 5 & 0 & 290 & 0 & 281 \\
\hline Nepal Majadur Kisan Party & 22 & 0 & 42 & 0 & 0 & 20 & 0 & 13 \\
\hline Nepal Lokatantrik Forum & 32 & 0 & 63 & 1 & 0 & 31 & 0 & 33 \\
\hline Nepali Janata Dal & 7 & 0 & 15 & 1 & 0 & 7 & 0 & 7 \\
\hline $\begin{array}{l}\text { Madheshi Janaadhikar Forum, } \\
\text { Nepal (Loktantrik) }\end{array}$ & 56 & 0 & 110 & 5 & 0 & 56 & 0 & 57 \\
\hline Rastriya Prajatantra Party & 58 & 1 & 104 & 4 & 0 & 56 & 0 & 50 \\
\hline Naya Shakti Party, Nepal & 22 & 0 & 42 & 1 & 0 & 21 & 0 & 21 \\
\hline $\begin{array}{l}\text { Communist Party of Nepal } \\
\text { (Marxist-Leninist) }\end{array}$ & 1 & 0 & 1 & 0 & 0 & 1 & 0 & 1 \\
\hline Nepal Pariwar Dal & 0 & 0 & 0 & 0 & 0 & 0 & 0 & 1 \\
\hline Bahujan Shakti Party & 8 & 0 & 16 & 0 & 0 & 8 & 0 & 10 \\
\hline Rastriya Janamukti Party & 3 & 0 & 6 & 1 & 0 & 6 & 0 & 4 \\
\hline Rastriya Janamorch & 33 & 0 & 77 & 0 & 0 & 35 & 0 & 34 \\
\hline $\begin{array}{l}\text { Rastriya Prajatantra Party } \\
\text { (Prajatantrik) }\end{array}$ & 2 & 0 & 4 & 0 & 0 & & 0 & 1 \\
\hline $\begin{array}{l}\text { Sangiya Lokatantrik } \\
\text { Rashtriya Manch }\end{array}$ & 1 & 0 & 4 & 0 & 0 & 1 & 0 & 1 \\
\hline Independent & 89 & 2 & 73 & 0 & 0 & 30 & 0 & 28 \\
\hline Grand Total & 6,680 & 62 & 13,220 & 264 & 0 & 6,742 & 0 & 6,567 \\
\hline
\end{tabular}

Note: Date extracted from Election Commission, 2074 BS

As in table-9 demonstrates, elected candidates in the post of chairpersons and members of the ward committee were men in large numbers. Women were very few in these posts. However, in the post of women members and dalit women members, because of reservation only for women, more than 13 thousand women are entertaining as members of the ward committee. 


\section{Conclusion}

The provision of reservation for women increases the number of participants in the electoral politics of women. It has proven by the local level election held in 2017. The constitution of Nepal, 2015 and the local level election act, 2017 lay down the mandatory provision for a political party to nominate women in the various post of the local level. A political party should list a minimum of 50 percent of women during the registration of their candidates on the post of chief and vice-chief of the local level. Similarly, two members of the ward committee are reserved only for women. These constitutional and legislative provisions have improved women's participation in the local level election. As a result, 57,844 women registered their file of candidacy and among them, 14,353 could win the election. Seven women won in the post of mayor of the municipality and 11 women got elected in the post of president of the RM. Similarly, 276 deputy mayor of the municipality and 424 vice-presidents of the RM are holding by women out of 753 local levels of the country. It is the highest number of women reached in the executive post of the local level in the political history of Nepal.

It is alleged that political parties fielded most of women candidates in the post of only vice-chief of the local level. Data regarding the election of the local level also prove it. More than 97 percent seats of the mayor of municipalities and the president of rural municipalities are occupied by men. More than 92 percent of seats of deputy mayor and vice-presidents of RM are won by women. But, the vice-chief is also an executive post of the local level. Vice-chief can play a decisive role in policymaking and implementation. Overall a woman gets the chance to understand the public affairs, its nature, and process. She will be used to keeping public relations, delivering public speeches, and addressing public grievances. These experiences of public life will help her to develop her overall personality and leadership capacity. After the five years term of vice-chief of the local level, she will be an eligible candidate for the post of chief of the local level for next term. Despite women are limited in the post of vice-chiefs, this situation provides the opportunity to prove their leadership skills. In this sense, it is a positive situation for women's participation in the elective office of the local level.

More than 13 thousand women get the chance to enter into the ward committee of the local level as its members. Half of them are dalit women. It is a matter of pride in the way of establishing inclusive democracy in the country. It became possible because of the reservation of two seats only for women out of four seats of the ward committee. However, among the elected candidates, more than 99 percent in the post of chairperson and more than 98 percent in the post of open members of the ward committee are men. These facts justify the need for the reservation for women in elective posts.

All over the country, 175 seats of dalit women members of the ward committee could not be fulfilled in the local election because of the lack of dalit women in the concerned ward. In such a case, alternative provision is needed to fulfill the post. The inclusion of women of 
different capacities or women belonging to the marginalized, minority, or indigenous groups may be the alternative solution to address this lack of dalit women. For this, the amendment should make in the local level election act, 2017.

This article focused on the number of women candidates on the local level election held in 2017. A visible number of women are working on the local level as people's representatives. They have passed two years and an odd period of public life experiences. How did they feel about their new experiences? How do their men counter partners respond to them? What is the response of common people, service receivers, and stack holders towards women representatives? These will be some of the themes for further research regarding women's participation in the Nepalese political field.

\section{References}

Bennett, L., Sijapati, B. \& Thapa, D. (2013). Gender and social exclusion in Nepal. Kathmandu: Himal Books.

Chalise, S. C. (1995). Sociology of the legislative elite in a developing society. Kathmandu: Nepal Foundation for Advanced Studies.

Chhetri, R. B. (2013). Women and men are the two wheels of the chariot: Rhetoric and realities of empowerment of women in Nepal (in Nepali). The conference on Inequality and Affirmative Action: Situating Nepal in Global Debates (pp. 75-80). Kathmandu: Social Science Baha.

Constitution of Nepal (2015). Kathmandu: Law Books Management Committee, Ministry of Law \& Justice, His Majesty's Govt. of Nepal

Dahlerup, D. \& Freidenvall, L. (2005). Quotas as a 'fast track' to equal representation for women. International Feminist Journal of Politics, 7(1), pp. 26-48, DOI: 10.1080/1461674042000324673

Election Commission (1992). General election in Nepal 1991, Kathmandu: Election Commission.

---. (2051 B.S.). House of Representatives members' election - 2051: election result description (in Nepali). Kathmandu: Election Commission.

---. (2056 B.S.). House of representatives members' election - 2056: Election result (in Nepali). Kathmandu: Election Commission.

---. (2065 B.S.). Constituent Assembly members' election 2064: Election result manual (in Nepali). Kathmandu: Election Commission. 
Dristikon: A Multidisciplinary Journal, December 2019, Vol. 9 No. 1

Election Commission (2070a B.S.). Constituent Assembly members' election 2070: Election result manual of first-past-the-post-election system (in Nepali). Kathmandu: Election Commission.

---. (2070b B.S.). Constituent Assembly members' election 2070: election result manual of proportional election system (in Nepali). Kathmandu: Election Commission.

---. (2015). Election in Nepal: Nepal's Electoral History. Retrieved from www.election.gov.np, Accessed: 10-09-2015.

---. (2074 BS). Local level election, 2074 BS (2017): Election result book (in Nepali). Kathmandu: Election Commission.

Gilardi, F. (2015). The Temporary Importance of Role Models for Women's Political Representation. American Journal of Political Science, 59(4), 957-970. http://www.jstor.org/stable/24582959, Accessed: 22-04-2018.

Gupta, A. (1964). Politics in Nepal. Bombay: Allied Publishers Pvt. Ltd.

Hachhethu, K. (2009). State building in Nepal: creating a functional state. Kathmandu: Enabling State Programme (ESP).

Kudva, N. (2003). Engineering elections: The experiences of women in "Panchayati Raj" in Karnataka, India. International Journal of Politics, Culture, and Society, 16(3), 445463. http://www.jstor.org/stable/20020176, Accessed: 22-04-2018.

Kumar, D. (2010). Electoral violence and volatility in Nepal. Kathmandu: Vajra Publications.

Lama, S., Khakurel, D., Agrawal, K., \& Shrestha, M. (2011). Women members of the Constituent Assembly: A study on contribution of women in constitution making in Nepal. Kathmandu: Women's Caucus, Constituent Assembly Secretariat, Nepal Law Society and International Institute for Democracy and Electoral Assistance.

Lawless, J. L. \& Fox, R. L. (2010). It still takes a candidate: Why women don't run for office (Revised edition). New York: Cambrridge University Press.

Local level election act (2017). Kathmandu: Law Books Management Committee, Ministry of Law \& Justice, His Majesty's Govt. of Nepal.

Malla, M. V. (2011). Political socialization of women in Nepal. New Delhi: Adroit Publishers.

Manchanda, R. (2008). Waiting for 'Naya' Nepal. Economic and Political Weekly (43/29), pp. 23-26. Rertieved from http://www.jstor.org/stable/40277737. Accessed: 08/12/2014.

Ministry of Federal Affairs and General Administration (MoFAGA) (2017). Local level detail list. http://www.mofald.gov.np/en (http://103.69.124.141/website/) 
National Democratic Institute for International Affairs (NDIIA). (2001). Nepal: Increasing Women's Political Participation (Quarterly Report. October 1 - December 31). Kathmandu: National Democratic Institute for International Affairs.

Palanithurai, G. (2002). Impediments to Empowerment of Women: Experiences of elected women representatives in panchayats in Tamil Nadu. The Indian Journal of Political Science, 63(1), 37-49. http://www.jstor.org/stable/42743573, Accessed: 22-04-2018.

Pokharel, B., \& Rana, S. (2013). Nepal: vote for peace. New Delhi: Cambridge University Press India Pvt. Ltd.

Pradhan, B. L. (2047 B.S.). People's revolution of Nepal, 2051 (in Nepali). Kathmandu: Rumu Prakashan.

Renaissance Society Nepal (RSN) (2009). Women's Political Participation, Empowerment and Inclusions in Nepal: Survey Report and Strategic Action Plan, 2009. Bhaktapur: Renaissance Society Nepal.

Shvedova, N. (2005). Obstacles to women's participation in parliament. In J. Ballington, \& A. Karam, Women in parliament: Beyond numbers (pp. 33-90). Stockholm: International Institute for Democracy and Electoral Assistance.

Thapa, M. S. (2013). Forget Kathmandu: An elegy for democracy. New Delhi: Aleph Book Company.

Tong, R. (2009). Feminist thought: A more comprehensive introduction ( $3^{\text {rd }}$ edition). Boulder, Colorado: Westview Press.

\section{Appendix}

\section{Gender-wise candidate and elected candidate in province level}

Gender-wise candidates and elected candidates of local level elections, 2017 (at Province one)

\begin{tabular}{|c|c|c|c|c|c|c|c|c|c|c|}
\hline \multirow{3}{*}{ Post } & \multicolumn{5}{|c|}{ Candidate } & \multicolumn{5}{|c|}{ Elected } \\
\hline & \multirow{2}{*}{ Total } & \multicolumn{2}{|c|}{ Man } & \multicolumn{2}{|c|}{ Woman } & \multirow{2}{*}{ Total } & \multicolumn{2}{|c|}{ Man } & \multicolumn{2}{|c|}{ Woman } \\
\hline & & $\mathrm{N}$ & $\%$ & $\mathrm{~N}$ & $\%$ & & $\mathrm{~N}$ & $\%$ & $\mathrm{~N}$ & $\%$ \\
\hline Mayor & 409 & 369 & 90.22 & 40 & 9.78 & 49 & 49 & 100.00 & 0 & 0.00 \\
\hline Deputy Mayor & 333 & 69 & 20.72 & 264 & 79.28 & 49 & 1 & 2.04 & 48 & 97.96 \\
\hline President of RM & 511 & 473 & 92.56 & 38 & 7.44 & 88 & 87 & 98.86 & 1 & 1.14 \\
\hline Vice-President of RM & 434 & 87 & 20.05 & 347 & 79.95 & 88 & 5 & 5.68 & 83 & 94.32 \\
\hline Ward Chairperson & 5329 & 5154 & 96.72 & 175 & 3.28 & 1156 & 1144 & 98.96 & 12 & 1.04 \\
\hline Member & 9437 & 9101 & 96.44 & 336 & 3.56 & 2312 & 2267 & 98.05 & 45 & 1.95 \\
\hline Women Member & 4552 & 0 & 0.00 & 4552 & 100.00 & 1156 & 0 & 0.00 & 1156 & 100.00 \\
\hline Dalit Women Member & 4062 & 0 & 0.00 & 4062 & 100.00 & 1145 & 0 & 0.00 & 1145 & 100.00 \\
\hline Grand Total & 25067 & 15253 & 60.85 & 9814 & 39.15 & 6043 & 3553 & 58.80 & 2490 & 41.20 \\
\hline
\end{tabular}


Gender-wise candidates and elected candidates of local level elections, 2017 (at Province two)

\begin{tabular}{|c|c|c|c|c|c|c|c|c|c|c|}
\hline \multirow{3}{*}{ Post } & \multicolumn{5}{|c|}{ Candidate } & \multicolumn{5}{|c|}{ Elected } \\
\hline & \multirow{2}{*}{ Total } & \multicolumn{2}{|c|}{ Man } & \multicolumn{2}{|c|}{ Woman } & \multirow{2}{*}{ Total } & \multicolumn{2}{|c|}{ Man } & \multicolumn{2}{|c|}{ Woman } \\
\hline & & $\mathrm{N}$ & $\%$ & $\mathrm{~N}$ & $\%$ & & $\mathrm{~N}$ & $\%$ & $\mathrm{~N}$ & $\%$ \\
\hline Mayor & 1111 & 1068 & 96.13 & 43 & 3.87 & 77 & 76 & 98.70 & 1 & 1.30 \\
\hline Deputy Mayor & 675 & 138 & 20.44 & 537 & 79.56 & 77 & 1 & 1.30 & 76 & 98.70 \\
\hline Pre & 659 & 641 & 97.27 & 18 & 2.7 & 59 & 59 & 100.00 & 0 & 0.00 \\
\hline Vic & 44 & 59 & 13.3 & 382 & 86.6 & 59 & 2 & 3.39 & 57 & 96.61 \\
\hline Warc & 8275 & 8052 & 97.31 & 223 & 2.69 & 1271 & 1262 & 99.29 & 9 & 0.71 \\
\hline Mer & 13389 & 12903 & 96.37 & 486 & 3.63 & 2542 & 2495 & 98.15 & 47 & 1.85 \\
\hline Wom & 6500 & 0 & 0.00 & 6500 & 100.00 & 1271 & 0 & 0.00 & 1271 & 100.00 \\
\hline Dalit Women Member & 6198 & 0 & 0.00 & 6198 & 100.00 & 1262 & 0 & 0.00 & 1262 & 100.00 \\
\hline Grand Total & 37248 & 22861 & 61.38 & 1387 & 38.62 & 6618 & 395 & 58.85 & 2723 & 41.15 \\
\hline
\end{tabular}

Gender-wise candidates and elected candidates of local level elections, 2017 (at Province three)

\begin{tabular}{|c|c|c|c|c|c|c|c|c|c|c|}
\hline \multirow{3}{*}{ Post } & \multicolumn{5}{|c|}{ Candidate } & \multicolumn{5}{|c|}{ Elected } \\
\hline & \multirow{2}{*}{ Total } & \multicolumn{2}{|c|}{ Man } & \multicolumn{2}{|c|}{ Woman } & \multirow{2}{*}{ Total } & \multicolumn{2}{|c|}{ Man } & \multicolumn{2}{|c|}{ Woman } \\
\hline & & $\mathrm{N}$ & $\%$ & $\mathrm{~N}$ & $\%$ & & $\mathrm{~N}$ & $\%$ & $\mathrm{~N}$ & $\%$ \\
\hline Mayor & 482 & 431 & 89.42 & 51 & 10.58 & 45 & 43 & 95.56 & 2 & 4.44 \\
\hline Deputy Mayor & 320 & 61 & 19.06 & 259 & 80.94 & 45 & 3 & 6.67 & 42 & 93.33 \\
\hline President of RM & 442 & 421 & 95.25 & 21 & 4.75 & 74 & 71 & 95.95 & 3 & 4.05 \\
\hline Vice-President of RI & 329 & 49 & 14.89 & 280 & 85.1 & 74 & 6 & 8.11 & 68 & 91.89 \\
\hline Ward Chairperson & 5359 & 5191 & 96.87 & 168 & 3.13 & 1121 & 1115 & 99.46 & 6 & 0.54 \\
\hline Member & 8870 & 8573 & 96.65 & 297 & 3.35 & 2242 & 2195 & 97.90 & 47 & 2.10 \\
\hline Women Member & 4312 & 0 & 0.00 & 4312 & 100.00 & 1121 & 0 & 0.00 & 1121 & 100.00 \\
\hline Dalit Women Member & 3499 & 0 & 0.00 & 3499 & 100.00 & 1070 & 0 & 0.00 & 1070 & 100.00 \\
\hline Grand Total & 23613 & 14726 & 62.36 & 8887 & 37.64 & 5792 & 3433 & 59.27 & 2359 & 40.73 \\
\hline
\end{tabular}

Gender-wise candidates and elected candidates of local level elections, 2017 (at Province four)

\begin{tabular}{|c|c|c|c|c|c|c|c|c|c|c|}
\hline \multirow{3}{*}{ Post } & \multicolumn{5}{|c|}{ Candidate } & \multicolumn{5}{|c|}{ Elected } \\
\hline & \multirow{2}{*}{ Total } & \multicolumn{2}{|c|}{ Man } & \multicolumn{2}{|c|}{ Woman } & \multirow{2}{*}{ Total } & \multicolumn{2}{|c|}{ Man } & \multicolumn{2}{|c|}{ Woman } \\
\hline & & $\mathrm{N}$ & $\%$ & $\mathrm{~N}$ & $\%$ & & $\mathrm{~N}$ & $\%$ & $\mathrm{~N}$ & $\%$ \\
\hline Mayor & 188 & 171 & 90.96 & 17 & 9.04 & 27 & 25 & 92.59 & 2 & 7.41 \\
\hline Deputy Mayor & 139 & 28 & 20.14 & 111 & 79.86 & 27 & 5 & 18.52 & 22 & 81.48 \\
\hline President of RM & 258 & 231 & 89.53 & 27 & 10.47 & 58 & 54 & 93.10 & 4 & 6.90 \\
\hline Vice-President of $\mathrm{R}$ & 206 & 37 & 17.96 & 169 & 82.04 & 58 & 9 & 15.52 & 49 & 84.48 \\
\hline Ward Chairpe & 2679 & 2558 & 95.48 & 121 & 4.52 & 759 & 744 & 98.02 & 15 & 1.98 \\
\hline Member & 4764 & 4573 & 95.99 & 191 & 4.01 & 1518 & 1480 & 97.50 & 38 & 2.50 \\
\hline Women Member & 2306 & 0 & 0.00 & 2306 & 100.00 & 759 & 0 & 0.00 & 759 & 100.00 \\
\hline Dalit Women Member & 2115 & 0 & 0.00 & 2115 & 100.00 & 728 & 0 & 0.00 & 728 & 100.00 \\
\hline Grand Total & 12655 & 7598 & 60.04 & 5057 & 39.96 & 3934 & 2317 & 58.90 & 1617 & 41.10 \\
\hline
\end{tabular}


Gender-wise candidates and elected candidates of local level elections, 2017 (at Province five)

\begin{tabular}{|c|c|c|c|c|c|c|c|c|c|c|}
\hline \multirow{3}{*}{ Post } & \multicolumn{5}{|c|}{ Candidate } & \multicolumn{5}{|c|}{ Elected } \\
\hline & \multirow{2}{*}{ Total } & \multicolumn{2}{|c|}{ Man } & \multicolumn{2}{|c|}{ Woman } & \multirow{2}{*}{ Total } & \multicolumn{2}{|c|}{ Man } & \multicolumn{2}{|c|}{ Woman } \\
\hline & & $\mathrm{N}$ & $\%$ & $\mathrm{~N}$ & $\%$ & & $\mathrm{~N}$ & $\%$ & $\mathrm{~N}$ & $\%$ \\
\hline Mayor & 365 & 328 & 89.86 & 36 & 9.86 & 36 & 36 & 100.00 & & 0.00 \\
\hline Deputy Mayor & 300 & 92 & 30.67 & 208 & 69.33 & 36 & 5 & 13.89 & 31 & 86.11 \\
\hline President of RM & 496 & 472 & 95.16 & 24 & 4.84 & 73 & 72 & 98.63 & 1 & 1.37 \\
\hline Vice-President of RM & 400 & 70 & 17.50 & 330 & 82.50 & 73 & 4 & 5.48 & 69 & 94.52 \\
\hline Ward Chairperson & 5031 & 4827 & 95.95 & 203 & 4.03 & 983 & 976 & 99.29 & 7 & 0.71 \\
\hline Member & 8559 & 8233 & 96.19 & 326 & 3.81 & 1966 & 1924 & 97.86 & 42 & 2.14 \\
\hline Women Member & 4105 & 0 & 0.00 & 4105 & 100.00 & 983 & 0 & 0.00 & 983 & 100.00 \\
\hline Dalit Women Member & 3778 & 0 & 0.00 & 3778 & 100.00 & 983 & 0 & 0.00 & 983 & 100.00 \\
\hline Grand Total & 23034 & 14022 & 60.88 & 9010 & 39.12 & 5133 & 3017 & 58.78 & 2116 & 41.22 \\
\hline
\end{tabular}

Note: Province five had two candidates from third sex; they could not win the election.

Gender-wise candidates and elected candidates of local level elections, 2017 (at Province six)

\begin{tabular}{|c|c|c|c|c|c|c|c|c|c|c|}
\hline \multirow{3}{*}{ Post } & \multicolumn{5}{|c|}{ Candidate } & \multicolumn{5}{|c|}{ Elected } \\
\hline & \multirow{2}{*}{ Total } & \multicolumn{2}{|c|}{ Man } & \multicolumn{2}{|c|}{ Woman } & \multirow{2}{*}{ Total } & \multicolumn{2}{|c|}{ Man } & \multicolumn{2}{|c|}{ Woman } \\
\hline & & $\mathrm{N}$ & $\%$ & $\mathrm{~N}$ & $\%$ & & $\mathrm{~N}$ & $\%$ & $\mathrm{~N}$ & $\%$ \\
\hline Mayor & 162 & 151 & 93.21 & 11 & 6.79 & 25 & 24 & 96.00 & 1 & 4.00 \\
\hline Deputy Mayor & 137 & 15 & 10.95 & 122 & 89.05 & 25 & 1 & 4.00 & 24 & 96.00 \\
\hline President of RM & 264 & 249 & 94.32 & 15 & 5.68 & 54 & 53 & 98.15 & 1 & 1.85 \\
\hline Vice-President of RM & 227 & 28 & 12.33 & 199 & 87.67 & 54 & 7 & 12.96 & 47 & 87.04 \\
\hline Ward Chairperson & 2594 & 2529 & 97.49 & 65 & 2.51 & 718 & 711 & 99.03 & 7 & 0.97 \\
\hline Member & 4735 & 4582 & 96.77 & 153 & 3.23 & 1436 & 1415 & 98.54 & 21 & 1.46 \\
\hline Women Member & 2293 & 0 & 0.00 & 2293 & 100.00 & 718 & 0 & 0.00 & 718 & 100.00 \\
\hline Dalit Women Member & 1990 & 0 & 0.00 & 1990 & 100.00 & 657 & 0 & 0.00 & 657 & 100.00 \\
\hline Grand Total & 12402 & 7554 & 60.91 & 4848 & 39.09 & 3687 & 2211 & 59.97 & 1476 & 40.03 \\
\hline
\end{tabular}

Gender-wise candidates and elected candidates of local level elections, 2017 (at Province seven)

\begin{tabular}{|c|c|c|c|c|c|c|c|c|c|c|}
\hline \multirow{3}{*}{ Post } & \multicolumn{5}{|c|}{ Candidate } & \multicolumn{5}{|c|}{ Elected } \\
\hline & \multirow{2}{*}{ Total } & \multicolumn{2}{|c|}{ Man } & \multicolumn{2}{|c|}{ Woman } & \multirow{2}{*}{ Total } & \multicolumn{2}{|c|}{ Man } & \multicolumn{2}{|c|}{ Woman } \\
\hline & & $\mathrm{N}$ & $\%$ & $\mathrm{~N}$ & $\%$ & & $\mathrm{~N}$ & $\%$ & $\mathrm{~N}$ & $\%$ \\
\hline Mayor & 234 & 217 & 92.74 & 17 & 7.26 & 34 & 33 & 97.06 & 1 & 2.94 \\
\hline Deputy Mayor & 202 & 24 & 11.88 & 178 & 88.12 & 34 & 1 & 2.94 & 33 & 97.06 \\
\hline President of RM & 256 & 246 & 96.09 & 10 & 3.91 & 54 & 53 & 98.15 & 1 & 1.85 \\
\hline Vice-President of RM & 221 & 14 & 6.33 & 207 & 93.67 & 54 & 3 & 5.56 & 51 & 94.44 \\
\hline Ward Chairperson & 3000 & 2898 & 96.60 & 102 & 3.40 & 734 & 728 & 99.18 & 6 & 0.82 \\
\hline Member & 5336 & 5103 & 95.63 & 233 & 4.37 & 1468 & 1444 & 98.37 & 24 & 1.63 \\
\hline Women Member & 2640 & 0 & 0.00 & 2640 & 100.00 & 734 & 0 & 0.00 & 734 & 100.00 \\
\hline Dalit Women Member & 2454 & 0 & 0.00 & 2454 & 100.00 & 722 & 0 & 0.00 & 722 & 100.00 \\
\hline Grand Total & 14343 & 8502 & 59.28 & 5841 & 40.72 & 3834 & 2262 & 59.00 & 1572 & 41.00 \\
\hline
\end{tabular}

Note: Data extracted from Election Commission, 2074 BS 